\title{
Geography in Geneva - New Trends
}

\author{
Antoine Bailly, Ruggero Crivelli, Charles Hussy, \\ Bertrand Lévy, Giuseppe Pini, Valérie November, \\ Geneva
}

Scarcely a day goes by without reminders of geographic problems and processes: health care problems like the AIDS epidemic, deterioration of the environment in the Alps, evolution of the perception of tourism and the tourist of the Swiss environment, transportation crisis through the Alps, increase of urban risks. Geographers in Geneva continuously develop new fields of research to interpret and explain the occurrence, distribution and interactions between these phenomena and to address these contemporary questions with more recent concepts and techniques. By means of theoretical and applied examples, this paper aims to show the broad spectrum of geography in Geneva which integrates environment and society, regional and global perspectives, as well as micro and macro approaches.

\section{Regional medicometry: a large research agenda}

The geography of health care is an established field which has found itself in the limelight in recent years due to concerns about rising costs and access to health care. Slower to develop are systematic analytical strategies for understanding the supply of and the demand for medical services in a regional context. The interdisciplinary undertaking designed to do exactly this is regional medicometry. It employs the combined viewpoints and the methods of geography, epidemiology, economics, sociology and regional science to develop a comprehensive analysis of the multifaceted aspects of modern health care systems. The field is developing rapidly. Useful medicometric research, which is able to contribute to the orientation of the medical and health care policies of our society, must be based upon a multidimensional approach; it must not neglect any of the actors in the health system. This consideration leads us to propose a definition of regional medicometry: the application of mathematical and statistical methods for the testing, the evaluation, and the prediction of medical regularities in space in such a manner as to incorporate the viewpoints of all the actors in the health system with an overall concern for issues of efficiency and equity.

A series of regional medicometry conferences have been held in Switzerland since 1983. These conferences have brought together university based researchers and physicians, industry based scientists, and managers from pharmaceutical companies, hospitals, and medical supply firms. Conference agendas have explored the causes of rising health costs, the nature of regional disparities in well-being and in the provision of health care services, the social and economic cost of illness, the economic impact of the health care system, and the changes to health care systems that are currently being made due to new medical technology. The last conference in 2003 presented the problems of an aging population on health care facilities and expenses, and the question of proximity of health infrastructures.

Regional medicometry is, simultaneously, a rigorous technical field utilising sophisticated modelling procedures, and an applied field concerned with the formulation of public policy and with the critical evaluation of public policy (Fig. 1). The principle distinguishing characteristic of regional medicometry is its broad, integrating perspective. From its origins in the mathematical modelling of the variation of medical regularities in space, regional medicometry has expanded to include issues related to the financing and the efficiency of health care delivery systems, as well as to the social and economic impact of the health care industry on regional systems (Fig. 2). It is evident that whereas considerable progress has been made in understanding the causes of rising health care costs and of regional disparities in well-being and in the provision of health care services much remains to be done. Regional medicometry brings new perspectives to the several critical questions that continue to confront those responsible for improving health care delivery.

For further details see BAILly 1993; BAILLY, BERNhard \& Gabella 2003; Bailly, Bridel \& Périat 1987; Bailly, Bridel \& Périat 1989; Bailly \& Coffey 1990; BAILly \& PÉriat 1985, 1995, 1998.

\section{New challenges for regional geography}

Regional geography is a discipline with many faces and uses, and as such can be approached in various ways. For us, it stems from human geography and draws its strength both from its spatial reference, and from specific problem areas. It allows researchers to analyse a society by looking at its practices and knowhow; both of which are dynamically evolving and intertwined with other regional spaces. This implies that regional geography simultaneously uses a spatial and a temporal approach: the temporal dimension brings us back to issues of social continuity or, to use other 


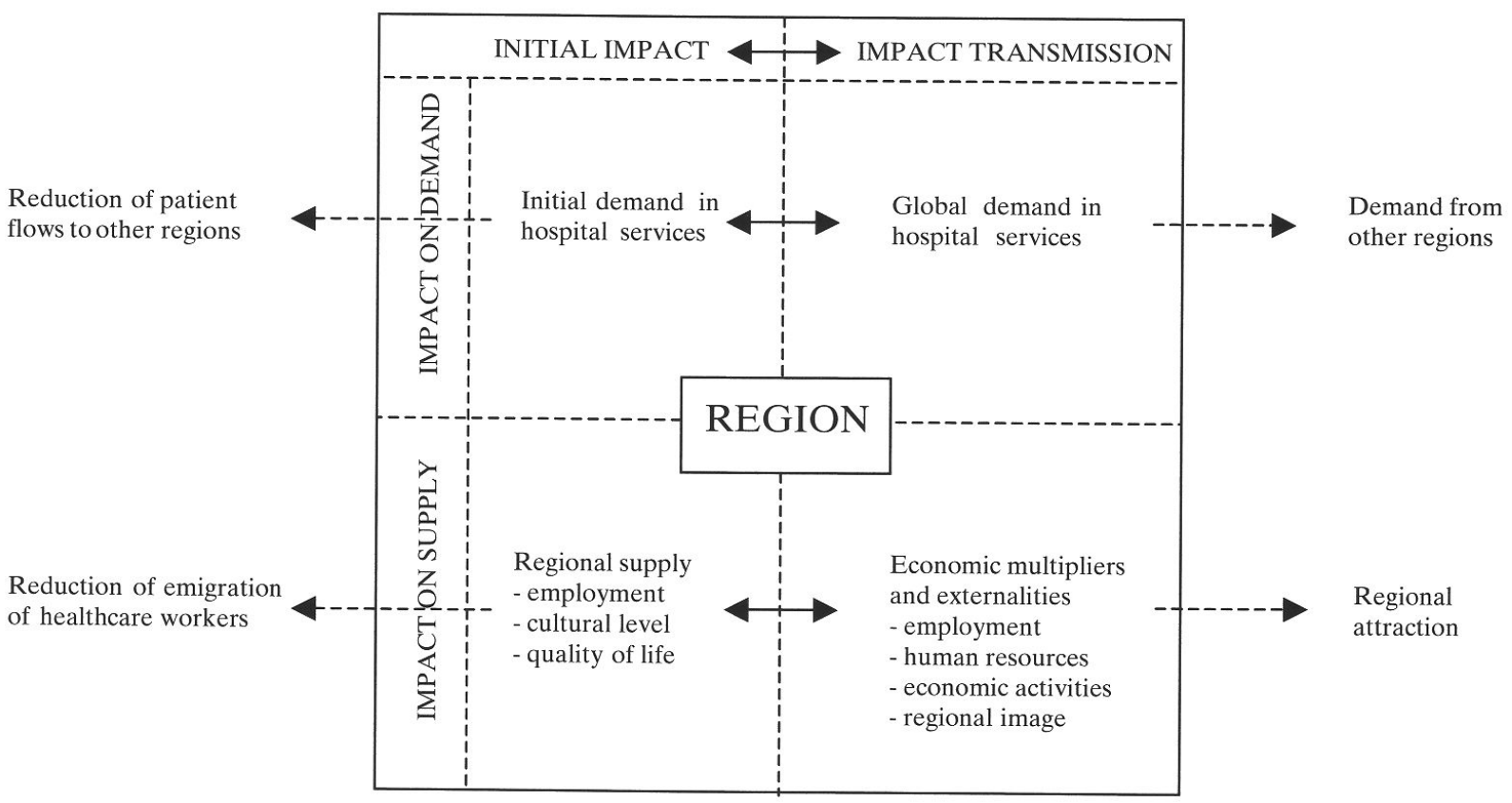

Figure 1: Regional impact of a hospital complex Regionale Auswirkungen eines Spitalkomplexes Impact régional d'un complexe hospitalier

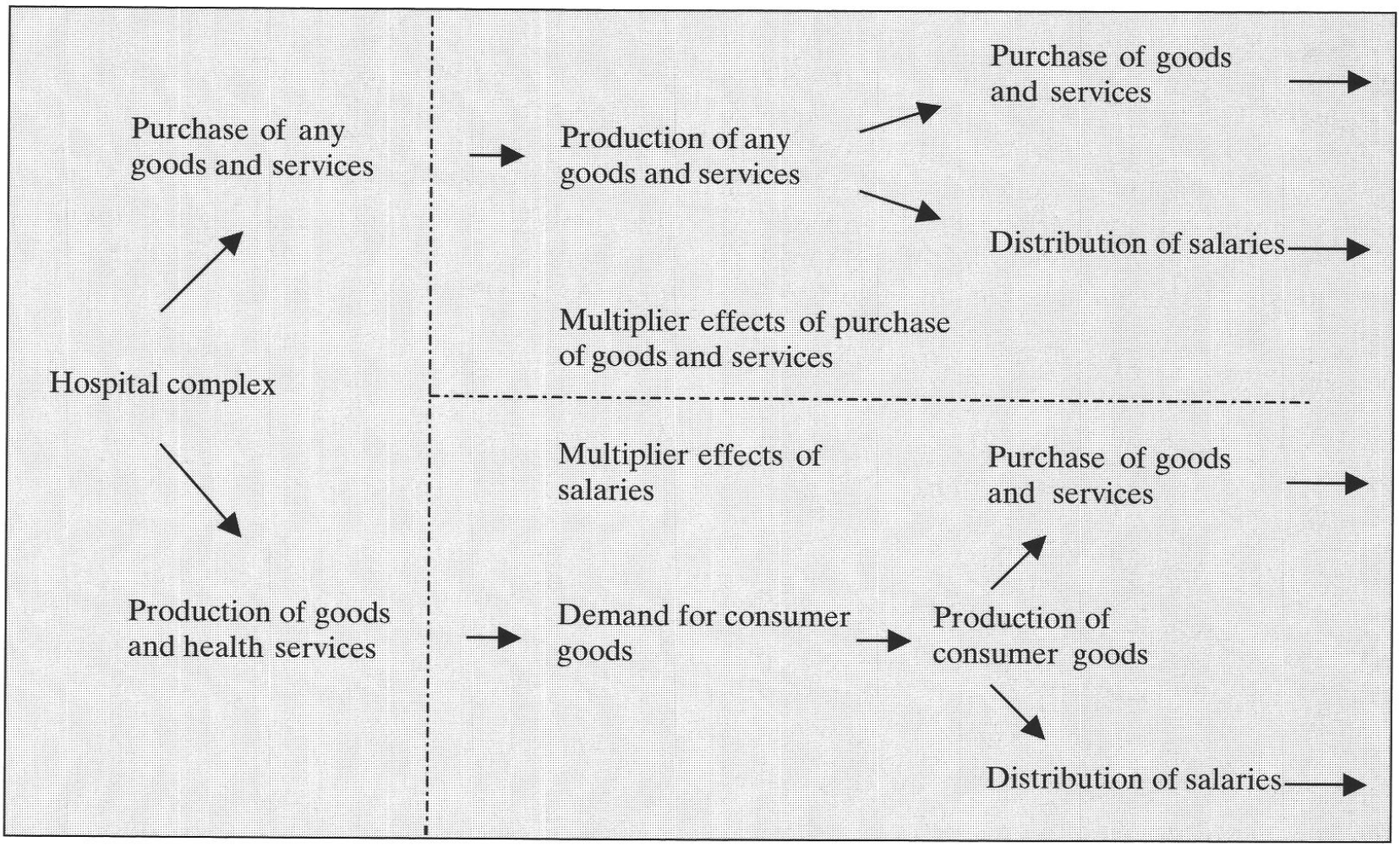

Figure 2: Direct and indirect economic impacts Direkte und indirekte ökonomische Auswirkungen Impacts économiques directs et indirects 
words, to the relationship between what is traditional and what is modern; the spatial dimension brings us back to the very heart of regional issues. All of these issues and approaches have changed dramatically over time.

For many years, geographers used representations of topography as a basis for determining regional spaces. Once such a division of space was done, the geographer would proceed to identify and study the footprints that societies had left on these spaces. Following this, and powered by the changes brought on by New Geography, geographers came back to this approach and suggested delimiting a region through the spatial expression of various functions, the focus being on economic functions. The first approach was essentially «ruralism», i.e. the projection of a region's own paradigms on itself (autopsy as a methodology and landscape as the object); the second leaned more towards practical intervention and quantitative analysis. The landscape thus lost its mosaic quality (nationalism, for example) to become a basis for interwoven relations. An approach focusing on economic functions does not allow the researcher to fix clear regional limits, nor to insist on their permanence. Regional geography, by placing emphasis on the relationships between different spatial entities, emphasises the links between varying scales. The region becomes an entity of varying geometric nature.

Regional geography today finds itself facing other questions following the changes in society. First of all, the fact that «region» has ceased to be spoken about exclusively by geographers (following an opening up towards more applied approaches) and that it has been transformed into a political object has brought back to the surface problem areas long forgotten, such as the question of identities, or rather, lived spaces (espaces vécus). Such forms of identity are based on collective (historical) experience of a common territory. Today's trend to «defunctionalise» national borders sets these identities free. Regional geography needs to find an answer to these questions - bearing in mind that such an answer is never neutral - because they concern issues of social integration and spatial justice.

Finally, regional geography concerns itself with environmental issues. Paradoxically, classical geography started from a physical substrate but without being aware of the interrelations between society and the environment. New Geography introduced the paradigm of complexity into its approaches, including such ideas as openness and interrelations, but erased the physical dimension. The development of ecology forced regional geography to face up to a problem that it didn't see coming, and forced it to integrate environmental issues into its framework. «Think globally, act locally» is a principle that seems to have been made specifically for regional geography, particularly when it comes to practical applications such as land use planning.

It is more urgent than ever before for regional geography to face each of these challenges by exchanging and sharing information with other disciplines.

For further details see Crivelli 1993, 1994, 1996, 1998, 1999.

\section{Geomatics}

The term geomatics appeared in engineering sciences with the emergence of new applications of information technology for land planning and management. The Department of Geography of the University of Geneva has taught and done research in this field since 1975 , opening the door for geographers to work in urban planning and environmental management, or in other fields such as health, education and tourism.

\subsection{Teaching: undergraduate programme and post-graduate specialisation}

Infographic techniques are useful and necessary for geographers because they facilitate geographers in the selection of the most appropriate techniques and approaches for analysing space. The undergraduate programme contains both general and specialised courses. All students follow lectures and practical seminars in graphic semiology, thematic cartography and data analysis. Specialised optional lectures include GIS (geographical information systems) and remote sensing. In addition, students are given the opportunity of obtaining a graduate certificate in geomatics, a course which includes 200 hours of lectures and an individual research project.

The department has at its disposal a computer laboratory equipped with Mapinfo, ArcView and Idrisi and infographic material. A specialised geomatics laboratory is available for working on individual research projects.

\subsection{Research: public and European consultancy projects}

The department has a research laboratory which carries out consultancy work for public institutions such as the Conseil du Léman. In collaboration with the Human Ecology Centre, research was done on the application of environmentel geomatics to local decision-making processes. The laboratory is currently working on a new project for the Canton of Geneva linked with the COST-C9 programme which aims to develop a new methodological tool that can be implemented by different actors, both in public and private spheres. The project aims to develop methodological concepts and innovative tools that aid urban manage- 


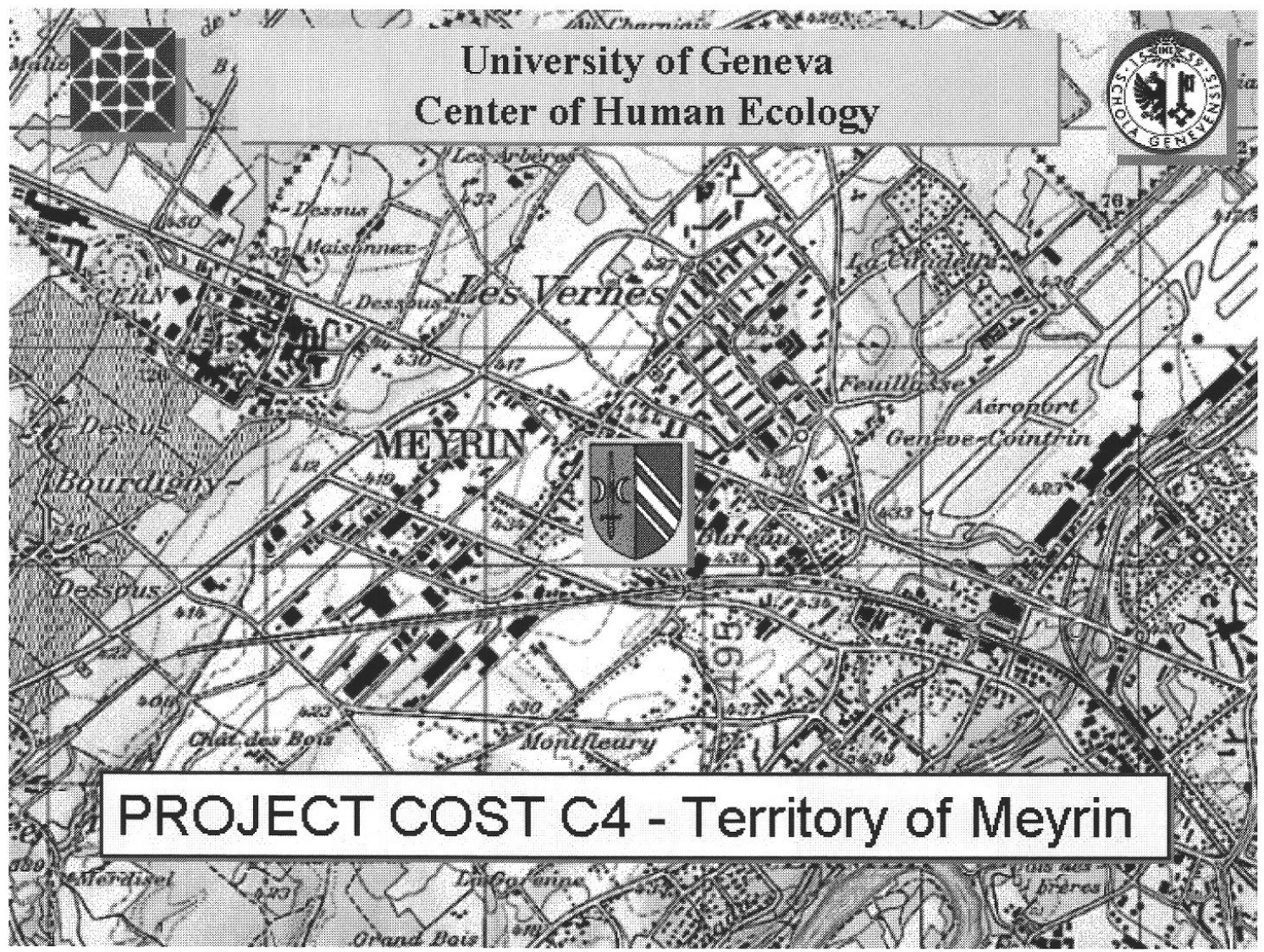

Figure 3: A local evaluation of sustainable urban planning

Lokale Evaluation nachhaltiger Stadtplanung

Une évaluation locale d'un aménagement urbain durable

ment and promote sustainable development in integrative city planning. It hopes to provide a better understanding of the functioning and evolution of the city so as to promote residential participation through a better integration of their needs in the urban planning decision process. This innovative approach is based on the way urban and sustainable indicators are structured, valued and used, on the way residents participate in the decision process and finally on the way actors' preferences are taken into account. Urban and sustainable indicators are listed in a flow chart of basic and general indicators. General indicators give a quick overview of the situation for the end-users and basic indicators can be considered for more detailed analysis. Finally, tools and methodologies developed in this project should allow a decision-making system to be set up which includes multiple criteria enabling actors to identify an acceptable compromise. The project plans to test the above described programme in the Canton of Geneva (Figure 3).

For further details see University Centre for Human Ecology 1999; Hussy 1998a, 1998b; Hussy et al. 1991.

\section{4 «Humanistic Geography» and tourism: a cultural perspective}

Courses and research in «Humanistic Geography» were introduced at the Department of Geography of the University of Geneva from 1992, ten years after the first publications on this branch of geography in the English- and French-speaking world. Nowadays humanistic geography is offered in several geography departments around the world, and the movement has deeply contributed to the renewal of cultural geography. The direct and especially the indirect influence of humanistic geography has been so strong that an historian of the discipline may assume in retrospective that human geography, after having experienced the paradigmatic change of «new geography» (i.e. quantitative methods) during the 1960s and 1970s, has gone through another paradigmatic change during the 1980s and 1990s, in the form of humanistic approaches (i.e. qualitative methods). A humanistic perspective conceives the world as a complex whole to be interpreted before being described and explained. This is why the hermeneutic methodology is at the heart of the humanistic approach. The 
contribution of hermeneutics was to enlarge traditional scientific sources of knowledge and methodologies with more subjective dimensions such as the artistic and ethical fields. Thus, E. KANT's «internal phenomena of man», i.e. values, symbols, beliefs, attitudes and behaviours, were incorporated into a spatial perspective. Other human and social sciences have also influenced the humanistic paradigm: microhistory, sociology and psychology of daily life and biographic course, as well as such approaches as the life-world characterising phenomenology and existential philosophy.

In Geneva, a great deal has been published on humanistic geography (LÉvy 1989,1992,1997), focusing on the intersection between the geography of lived space in travel writing and landscape descriptions in the light of epistemological arguments provided by existential philosophies. More recently, an interdisciplinary research project on the ideal model of the city was undertaken (LÉVY \& RAFFESTIN 1999). A Swiss National Fund Project related to tourism was also carried out (LÉvy, Matos \& RAFFestin 2002). Tourism is seen as a phenomenon that has a lot to do with lived space and landscape experience since one of the main motivations of tourism is the multiple quest for the ideal place to temporarily live. Thus tourism is considered to be the experience of place and landscape at different scales. Scales of perception vary from regional to microlocal (e.g. the hotel room as the living space of the tourist par excellence), including cities, neighbourhoods and various characteristic local urban features. To encompass the touristic phenomenon as a whole, the authors moved along the objective/ subjective axis of language by integrating a certain amount of economic and demographic data, such as for instance the number of arrivals, nights spent, and international quantitative comparisons. The project led to proposals that affected the fields of tourism and culture, tourism and land use, as well as tourism and urban life (Table 1).

\section{Transport geography}

The geographer's interest in transport stems from the close link between the transportation system and the spatial organisation of society. Indeed, the transportation system allows the integration of places and supports the economic and social cohesion of an area. It contributes to the creation and the functionality of a territory and of places of living and society. As our living space incorporates different scales of perception, the transportation system ensures both the interconnection and the «operationality» of the area.

\subsection{A systems theory}

The geography of transport as taught by the Department of Geography of the University of Geneva uses the systems theory to take into account the multiple interrelations which the transportation system maintains with its human and physical operational environment. The various elements composing the operational environment determine the needs for transport and/or constitute the resources necessary for transport activity. They have primarily two functions: a function of control (e.g. on operation and impacts) and a function of constraint (need fulfilment and resource utilisation). Both functions are affected by the same elements. The transportation system has economic (employment, added value), spatial (spatial organisation of society, place accessibility) and ecological (harmful effects and pollution) effects (Figure 4).

\subsection{A broad spectrum of research}

The systems theory is used in a broad range of theoretical and empirical research on problem areas in transport policy, management of mobility, regional planning, and access to work, shopping and places of leisure.

Research undertaken made it possible to thoroughly investigate theoretical and/or operational elements like, for example, accessibility and access (access being the expectations individuals have in the quality of the transportation services to reach work, shopping and places of leisure) concepts and their contribution to sustainable mobility (Martinelli, Pini, Torricelli \& WIDMER 2000), the concepts of modal complementarity and interface (PINI, Joost, WidMER \& BRIDEL 2000), as well as the identification of the conditions of respect in the decision making process and the definition of transport policies in border areas (PINI \& WidMeR 2000).

Intense empirical research on hierarchy characterises the geography of transport practised in Geneva. The Mobility Observatory (OUM) of the Department of Geography has specialised itself over the last few years in socio-economic impact studies relating to transport, in the analysis of the behaviour of mobility in urban environments and in mobility management policies. Among their recent projects, the OUM researchers have measured the sensitivity of consumers to a change of accessibility within the city centre (ANTILLE, JAUNIN, WidMer \& PINI 1999a, 1999b), have worked with the authorities on a procedure of compensation for tradesmen negatively affected by the building of a tramway (Lier, Widmer \& Pini 2000), have identified the necessary steps to improve the use of park-and-ride facilities (P+R) (BARbey \& Pini 2000) and have evaluated the impacts of increased pedestrian areas on retail activities in the city centre of Geneva (BoIllat, Widmer \& PinI 


\begin{tabular}{|c|c|c|c|}
\hline City & Hotel nights & $\begin{array}{l}\% \text { foreign } \\
\text { nights }\end{array}$ & $\begin{array}{l}\text { Stay duration } \\
\text { (days) }\end{array}$ \\
\hline 1. Zurich & 2233000 & 78 & 2,0 \\
\hline 2. Geneva & 1911000 & 85 & 2,3 \\
\hline 3. Zermatt & 1257000 & 69 & 3,2 \\
\hline 4. Lucerne (*) & 920542 & 78 & 1,3 \\
\hline 5. Lugano $(*)$ & 927000 & 65 & 2,2 \\
\hline 6. St-Moritz & 902000 & 70 & 3,2 \\
\hline 7. Davos & 891000 & 59 & 4,0 \\
\hline 8. Lausanne (*) & 826000 & 68 & 2,1 \\
\hline 9. Interlaken & 682000 & 84 & 2,0 \\
\hline 10. Zurich airport & 670000 & 70 & 1,6 \\
\hline 11. Basel & 645000 & 69 & 1,6 \\
\hline 12. Locarno & 553000 & 43 & 2,8 \\
\hline 13. Grindelwald & 549000 & 76 & 2,8 \\
\hline 14. Berne & 534000 & 59 & 1,9 \\
\hline 15. Arosa & 511000 & 41 & 4,4 \\
\hline 16. Ascona & 435000 & 48 & 3,4 \\
\hline 17. Montreux & 403000 & 63 & 2,4 \\
\hline $\begin{array}{l}\text { 18. Crans- } \\
\text { Montana }\end{array}$ & 402000 & 54 & 4,6 \\
\hline 19. Pontresina & 382000 & 58 & 4,7 \\
\hline 20. Saas Fee & 366000 & 56 & 4,0 \\
\hline 24. Meyrin & 264000 & 81 & 1,7 \\
\hline
\end{tabular}

(*) and surroundings

Table 1: The most popular tourist destinations in Switzerland (2000)

Die populärsten Touristenziele der Schweiz (2000)

Les destinations touristiques les plus populaires en Suisse (2000)

Source: LÉvy, Matos \& RafFestin 2002; based on Office Fédéral de la Statistique (OFS) 2001

2001). They have also investigated the relation between mobility and consumption within the city centre (BoILLAT, WIDMER \& PINI 2002) and the presence of the bicycle and obstacles to its use (Boillat, Norer \& PinI 2002) (Figure 5).

These various directions of research show, on the one hand, the intensity with which geography of transport is practised at the University of Geneva, an intensity which is reflected in the courses offered and in the pro- ductivity of its academic research. On the other hand, the spectrum of research underlines the role transport plays in the functionality and management of regions in our societies.

\section{Geography of risk: understanding complexity}

Risk analysis is not new to geography. From the beginning geography paid attention to several kinds of risks, 


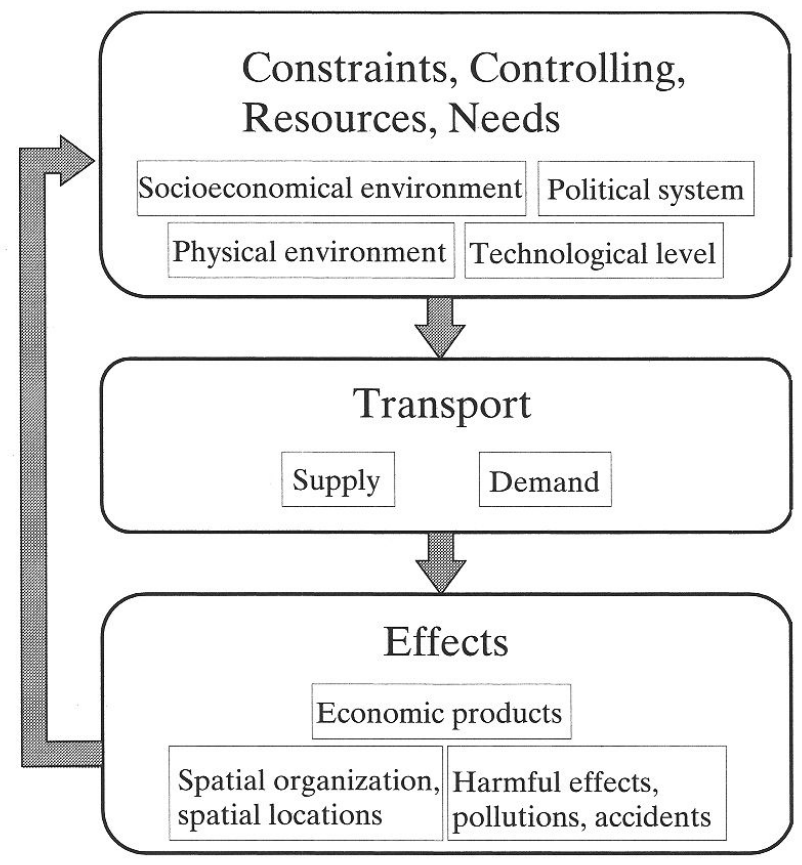

Figure 4:Transportation system

Das Transportsystem

Le système de transport

be it floods, landslides or earthquakes. We can find early investigations on flood risk, for instance, among American geographers since the 1940's, like G. White, and also among Spanish, French and Swiss geogra- phers. However, risk analysis by means of modelling and case studies is more pronounced in physical geography. In human geography, many studies have analysed the reactions of individuals confronted by risks. These studies have pointed out that different types of risks (natural, social, environmental or industrial) have common factors and could therefore be studied collectively as follows: every risk requires skills in public and private management, as well as knowledge on how to reduce or mitigate the risk. Each kind of risk also requires an identification process (analysis before taking action).

In Geneva, we have focused our research on the study of the space-time logic of risk (Fig. 6). Risks always have spatial consequences. Our studies incorporate both theoretical and pragmatic approaches.

On the theoretical side, we see that in spite of the fact that many different ways of considering territory exist, the functional approach to space predominantly determines the risk and risk management approach. The same applies to risk itself; there are many different approaches to risk but the most widely adopted is the one based on probability. The choice of these two approaches literally dictates the way risk is managed and therefore also the way the relation between risk and space is investigated. Similarly, both proximity and density are crucially important factors of risk, yet distance is the factor systematically chosen. Our research in Geneva shows that by limiting risk analysis to the functionality and probability approaches, a part of the

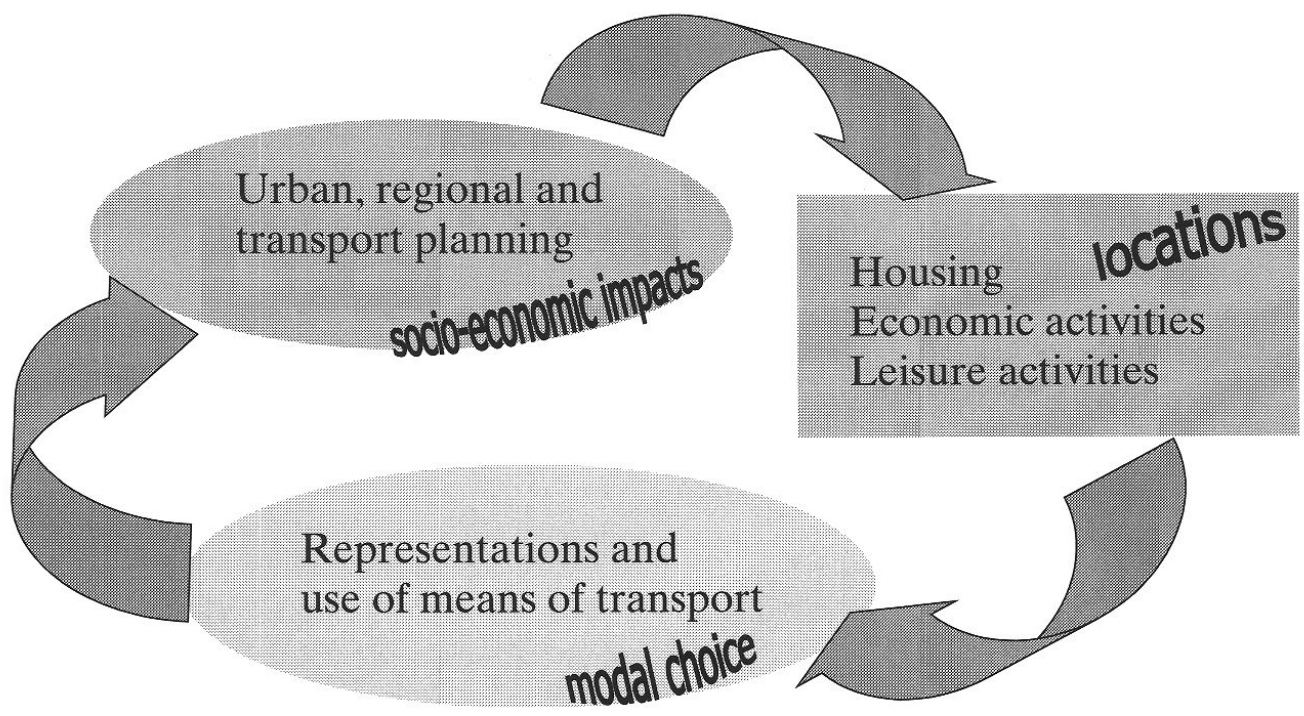

Figure 5: Fields of research in transport geography in Geneva

Forschungsgebiete der Transportgeographie in Genf

Domaines de recherche en géographie des transports à Genève 


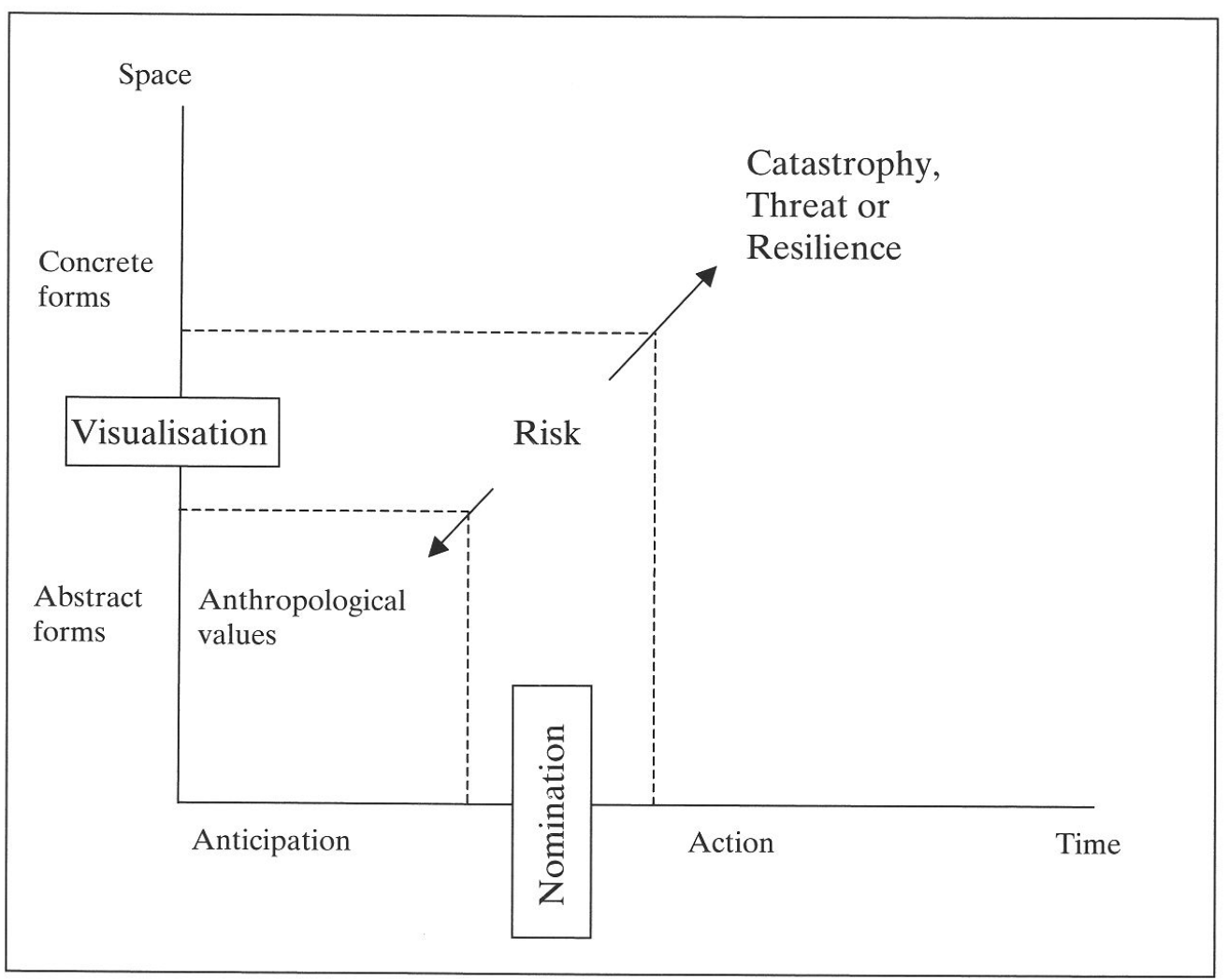

Figure 6: Space-time logic of risk

Raum-Zeit-Logik des Risikos

La logique espace-temps du risque

relations between space and risk will remain undiscovered. We consider the most important factor in risk analysis is not proximity (or contiguity) between activities, but rather connectivity, which enables us to take into account not only a number of different approaches, but also the spatial aspect of risk.

On the pragmatic side, we have concentrated our field research on urban risks, e.g. the process of risk identification of firemen. We have also recently begun research on CCTV (close-circuit television). Managing risks requires the development of surveillance devices able to precisely document the situation at hand. This documentation step is a prerequisite for adequate reaction and action initiation. Our investigation examines from a geographical perspective, how CCTV devices interfere and transform public places. If, on the one hand, the characteristics of the area being watched determine the type of CCTV to be operated, depending on the identified risks, on the other hand, CCTV plays an important role in transforming public places, notably by increasing the amount of private security within the public domain.

For further details see November 1994, 1999, 2002;
November et al. 1998; November, Klauser \& RuegG 2002.

\section{References}

Regional medicometry: a large research agenda

BAILLY, A. (1993): Health policy in Switzerland». - In: CASPARIE, A. et al. (eds): Health care in Europe after 1992, Aldershot: Ashgate: 27-48.

Bailly, A., Bernhardt, M. \& M. Gabella (2003): Pour une santé de qualité en Suisse. - Paris: Economica.

Bailly, A., Bridel, F. \& M. Périat (eds) (1987): La Santé: Perspectives Médicales. - Geneva, Paris: Economica.

Bailly, A., Bridel F. \& M. Périat (eds) (1989): L'assurance Maladie: Solutions Actuelles et Futures. Geneva, Paris: Economica.

Bailly, A. \& W. Coffey(1990): Regional Medicometry: Health Expenditures, Regional Disparities, Problems and Policies. - In: Boyce, D. et al. (eds): Regional Science. - Heidelberg: Springer-Verlag: 469-485.

Bailly, A. \& M. Périat (eds) (1985): Médicométrie Régionale. - In: Revue d'Economie Régionale et Urbaine, special issue. 
BAILLY, A. \& M. PÉRIAT (1995): Médicométrie: une nouvelle approche de la santé. - Paris: Economica.

BAILlY, A. \& M. PÉRIAT (eds) (1998): Regional Medicometry: Epistemological Bases and Case Studies. In: Applied Geographic Studies 2, 2:145-155.

\section{New challenges for regional geography}

Crivelli, R. (1993): Société traditionnelle, société moderne et nature. - In: Economie-écologie dans le contexte de l'arc alpin. - Berne: Verlag Paul Haupt: 215-227.

CRIVELLI, R. (1994): Rationalité et vie quotidienne en montagne: un regard historique. - In: Revue de Géographie Alpine 3, Tome LXXXII, Grenoble: 95-106.

CRIVELLI, R. (1996): Les Alpes sont-elles une région? Réflexions autour de leur spécificité, autonomie et dépendance. - In: Le Globe, Tome 136, Genève, Société de Géographie de Genève: 25-31.

Crivelli, R. (1998): L'industrializzazione delle Alpi, prospettive storiche e attuali. - In: ScAramellini Guglielmo (red.): Montagne a confronto, Alpi e Appennini nella transizione attuale. - Torino: G. Giappichelli Editore: 99-116.

CRIVELLI, R. (1999):Territoire et argent:la mise en place de la déterritorialisation. - In: Pfister, B., CRIVELli, R. \& M. ReY: Finances et territoires, leur place dans la prise de décision publique. - Lausanne: Presses Polytechniques et Universitaires Romandes: 217-226.

\section{Geomatics}

University Centre for Human Ecology (CUEH) (1999): Information and Decision Support Systems for the Management of Integrated Urban Civil Engeenering: Case study in Meyrin. - In: Cahier du CUEH, Action Cost C4, gestion et développement des applications de l'information en génie civil urbain. Etude de cas: La Commune de Meyrin, No. 3, Genève: CUEH.

Hussy, C. (1998a): Signifier and Signified: Beetween Insignificance and Operability. - In: PrIETO, L.J. \& P. Pellegrino, Semiotica 122: 297-308.

Hussy, C. (1998b): La carte, un modèle, un langage. Genève. - Université de Genève, département de géographie.

Hussy, C. et al.: Atlas du Bassin Genevois et de la Région Lémanique. Un espace transfrontalier au cœur de l'Europe. - Genève: Encyclopédie de Genève.

\section{«Humanistic Geography» and tourism: a cultural perspective}

LÉvY, B. (1989): Géographie humaniste et littérature: l'espace existentiel dans la vie et l'œuvre de Hermann Hesse (1877-1962). - Genève: Le Concept moderne. LÉvy, B. (1992): Hermann Hesse. Une géographie existentielle. - Paris: José Corti.

LÉvy, B. (1997): Géographie humaniste, géographie culturelle et littérature. Position épistémologique et méthodologique. - In: Géographie et cultures 21:27-44.
LÉvY, B. (ed.) (1997): Le voyage à Genève. Une géographie littéraire. Stendhal, Chateaubriand, Dumas, Flaubert, Nerval, Gautier, Cochet, Bauër, Gascar, Bouvier. - Genève: Metropolis.

LÉvy, B., MATOS, R. \& S. RAFFestin (1998): L'évolution de la représentation du Léman à travers les guides et la promotion touristique du XIXe siècle à nos jours: le cas genevois. - In: Le Globe 138, Genève, Société de Géographie: 73-92.

LÉvy, B., Matos, R. \& S. RafFestin (2002): Le tourisme à Genève. Une géographie humaine. - Genève: Metropolis.

Lévy, B. \& C. RAFFestin (éd.) (1999): Ma ville idéale. Nicolas Bouvier, Luc Bureau, Jean-Paul Dollé, Franco Farinelli, Jean-Pierre Gaudin, Predrag Matvejevich, Claude Raffestin, Kenneth White. - Genève: Metropolis.

Newby, P.T.(1981): Literature and the Fashioning Tourist Taste. - In: Pocock, D.C.D. (éd.): Humanistic Geography and Literature. Essays on the Experience of Place. - London: Croom Helm: 130-141.

Office Fédéral de la Statistique (OFS) (2001): Les hôtels et les établissements de cure en Suisse. Neuchâtel: Office Fédéral de la Statistique.

\section{Transport geography}

Antille, F., Jaunin, V., Widmer, G. \& G. Pini (éd.) (1999a): Rue de Lausanne: accessibilité et retombées économiques des utilisateurs des moyens de transport. - Office des transports et de la circulation, Mobilité 2005, rapport E 2b, Genève.

Antille, F., Jaunin, V., Widmer, G. \& G. Pini (éd.) (1999b): Sensibilité des activités économiques et des utilisateurs à la desserte. - Office des transports et de la circulation, Mobilité 2005, rapport E 2a, Genève.

BARBEy, J. \& G. Pini (éd.) (2000): Analyse des facteurs de réussite des parcs relais de Genève. - Genève: Fondation des Parkings.

Boillat, P., Norer, O. \& G. Pini (2002): Représentations du vélo et obstacles à son utilisation à Genève. - Planification Sanitaire Qualitative, Département de l'Action Sociale et de la Santé, Canton Genève.

Boillat, P., Widmer, G. \& G. Pini (éd.) (2001): Répercussions socio-économiques d'une extension du secteur à priorité piétonne dans le centre-ville de Genève. - Département de l'Aménagement, des Constructions et de la Voirie, Service d'urbanisme, Ville de Genève. Boillat, P. Widmer, G. \& G. Pini (2002): Mobilité et consommation: le cas du centre ville de Genève. Office des transports et de la Circulation, Canton de Genève.

Lier, T., Widmer, G. \& G. Pini (éd.) (2000): Estimation des indemnisations dues aux travaux de réalisation d'une ligne de tramway. - Département de l'Aménagement de l'Environnement et du Logement (DAEL), Genève.

Martinelli, A., Pini, G., Torricelli, G.P. \& G. Widmer 
(2000): Indicateurs d'accès pour une mobilité durable. - Projet A11, Programme National de Recherche 41, (Transport et environnement), Direction du PNR41, Volume A11, Berne.

Pini, G., Joost, S., Widmer, G. \& L. Bridel (éd.): Interfaces de transports: interfaces de territoires. - Actes du séminaire de 3e cycle de Géographie, mars-mai 1999, Lausanne, Conférence Universitaire Suisse Occidentale.

Pini, G. \& G. Widmer (2000): Les transports transfrontaliers dans la région de Genève. - Projet D7, Politiques de transport et régions frontalières: bilans, prospectives, modes d'emploi, Programme National de Recherche 41, (Transport et environnement), Direction du PNR41, Volume M14, Berne.

\section{Geography of risk: understanding complexity}

November, V. (1994): Risques naturels et croissance urbaine: réflexion théorique sur la nature et le rôle du risque dans l'espace urbain. - In: Revue de Géographie Alpine 4:113-123.

November, V. (1999): Le risque aurait-il une dimension cachée? - In: Genève XXIe siècle: 21 défis et 21 talents pour les relever. - Genève: Ed. Edito: 196-199.

November, V. (2002): Les territoires du risque: le risque comme objet de réflexion géographique.-Berne: Peter Lang.
November, V., Klauser, F. \& J. Ruegg (2002): Risques sous surveillance: une analyse géographique de l'utilisation de la vidéosurveillance. - Ethique publique 4, 2: 153-164.

November, V. et al. (1998): La représentation des risques naturels en montagne. Avant-propos. - In: Revue de Géographie Alpine 2:7-9.

Prof. Dr. Antoine Bailly, Dr. Ruggero Crivelli, Prof. Dr. Charles Hussy, Dr. Bertrand Lévy, Prof. Dr. Giuseppe Pini, Dr. Valérie November, Département de Géographie, Université de Genève, 40, bd du Pontd'Arve, CH-1211 Genève 4.

\section{Internet address}

Département de Géographie:

http://www.geo.unige.ch/ 